\title{
What do Turkish sports science students know about dental trauma and mouthguards? A descriptive study
}

\author{
Cansu Özşin Özler (D) ," Bahar Güçiz Doğan, ${ }^{2}$ \\ Emre Bilgin, ${ }^{3}$ Gıyasettin Demirhan, ${ }^{3}$ Dicle Aras, ${ }^{4}$ \\ Ebru Çetin, ${ }^{5}$ Hayrunnisa Şimşek, ${ }^{1}$ \\ Meryem Uzamış Tekçiçek ${ }^{1}$ \\ ${ }^{1}$ Department of Pediatric Dentistry, Faculty of Dentistry, \\ ${ }^{2}$ Department of Public Health, Faculty of Medicine, ${ }^{3}$ Faculty \\ of Sport Sciences, Hacettepe University, ${ }^{4}$ Faculty of Sport \\ Sciences, Ankara University, ${ }^{5}$ Faculty of Sport Sciences, \\ Gazi University, Ankara, Turkey
}

\begin{abstract}
ОвJестіVE: Sports-related dental and orofacial injuries can be reduced significantly through training on primary prevention and using proper equipment before engaging in sporting activities. This study aimed to determine the level of knowledge regarding dental trauma and prevention by mouthguards among the students in the Faculty of Sport Sciences.

MAterials AND Method: This was a descriptive study conducted at Ankara, Gazi, and Hacettepe Universities. Although intended to include all students at the faculties $(\mathrm{N}=3097)$, only those who were at the faculty and volunteered $(28.2 \%)$ on the day the data were gathered participated. Data were gathered via a questionnaire comprising 31 questions on sociodemographic characteristics, dental trauma history, mouthguard use, and knowledge of dental trauma.

RESULTS: In total, 875 students with a mean age of $22.5 \pm 2.9$ (60.3\% male) participated. Of these students, $20.6 \%$ had dental trauma history, $\mathbf{7 2 . 0 \%}$ had first aid and emergency training, and $20.9 \%$ had oral dental injuries training. Of the students, $69.5 \%$ had heard about mouthguards, although only $19.7 \%$ of these had used them. Mouthguards were mostly used in professional sports activities such as fareastern sports and ice hockey. The average number of true answers out of ten dental trauma-related questions was $2.75 \pm 1.68$ and $66.6 \%$ stated they wished to learn more about the topic.
\end{abstract}

Received: August 6, 2019; Accepted: December 24, 2019

${ }^{*}$ Corresponding author: Dr. Cansu Özșin Özler, Hacettepe University, Faculty of Dentistry, Department of Pediatric Dentistry, 06100, Ankara, Turkey;

E-mail: cansu.ozsin@ hacettepe.edu.tr
Conclusion: Results showed a lack-of-knowledge about both dental trauma and mouthguards and inadequate use of mouthguards in sports activities. Therefore, basic information about these topics should be implemented in the curriculum to instruct students before they graduate.

KEYWORDS: Knowledge; mouthguards; sports injuries; students; tooth avulsion; trauma

Citatıon: Özşin Özler C, Güçiz Doğan B, Bilgin E, Demirhan G, Aras D, Çetin E, Şimşek H, Uzamış Tekçiçek M. What do Turkish sports sciences students know about dental trauma and mouthguards? A descriptive study. Acta Odontol Turc 2020;37(2):29-35

EdıToR: Güven Kayaoğlu, Gazi University, Ankara, Turkey

Copyright: (C) 2020 Özşin Özler et al. This work is licensed under a Creative Commons Attribution License. Unrestricted use, distribution and reproduction in any medium is permitted provided the original author and source are credited.

FundiNG: None declared.

CONFLICT OF INTEREST: The authors declare no conflict of interest related to this study.

\section{INTRODUCTION}

Orofacial and dental injuries might occur due to falls, collisions, contact with hard surfaces, or contact with equipment. For both children and adults, injury is a possibility during sports activities..$^{1-3}$ Facial injuries related to sport accidents account for $8 \%$ of all facial soft tissue injuries and $11-40 \%$ of all sports injuries involve the face. ${ }^{4,5}$ Sports-related dental and orofacial injuries affect mostly the upper lip, maxillary jawbone, and maxillary incisors. ${ }^{2,6}$ Children and adolescents, in particular, have increased risk for dental trauma from sporting activities due to the ongoing growth of the maxilla and alveolar bone, existence of immature permanent teeth, and behavioral challenges. ${ }^{7}$ In the literature, baseball was the most risky sport for dental injuries among the 7-12 year age group, whereas basketball was the most risky in the 13-17 year age group. ${ }^{8}$ Orofacial and dental trauma is a serious public dental health problem ${ }^{9}$ with significant consequences for children and their parents, which may affect their quality of life due to the potential pain, negative psychological effects, and economic burden of treatment needs. ${ }^{2,10}$ 
Dental and facial injuries can be reduced significantly through introducing training on primary prevention and using proper equipment before engaging in sporting activities. Most sports-related traumatic dental injuries are preventable with mouthguards. ${ }^{8,11}$ The American Dental Association and International Academy of Sports Dentistry recommend mouthguard use in 29 sports/exercise activities. ${ }^{2,8}$

Athletes, coaches, athletic trainers, and recreation leaders should be aware of the risk for dental trauma in sports activities. ${ }^{12}$ Studies of people involved in professional sports activities show they have low level dental trauma knowledge. ${ }^{13-15}$ Considering that Sport Sciences Faculty students will continue their professional lives as physical education teachers or coaches, it is crucial for them to have correct sports-related dental trauma knowledge to protect their students as well as themselves. To the best of the authors' knowledge, there is no study in Turkey about dental trauma knowledge and mouthguard use of students in Sport Sciences Faculties. Therefore, this study aimed to reveal the knowledge of the students in the Faculty of Sport Sciences on the prevention and management of dental trauma and determine the level of mouthguard use.

\section{Materials and Method}

\section{Place and time of research}

This descriptive study was conducted with students enrolled in the Faculty of Sport Sciences of three universities located in Ankara, the capital city of Turkey (Ankara, Gazi, and Hacettepe Universities). Ethical approval from Hacettepe University Non-Interventional Clinical Research Ethics Board (Decision No: GO 17/369-27) and the Faculty deans' written official permissions were obtained. The data were gathered between April and December 2017.

\section{Universe and sample}

The inclusion criteria were being a student of the targeted faculties and volunteering to participate. Although intended to cover all students of the faculties (3097 students), only $875(28.3 \%)$ students participated in the study. There were four departments in the faculties: Physical Education and Sports Teacher Education, Recreation, Coaching Education, and Sports Management. Of the 875 participants, 333 were students in the Department of Physical Education and Sports Teacher Education, 146 were in the Department of Recreation Leaders, 223 were in the Department of Coaching Education, and 173 were in the Department of Sports Management.

\section{Data collection}

The data were gathered via a structured, pre-tested, self-administered questionnaire. The pre-test was performed with 20 other faculty students of similar ages in order to check the comprehensibility of the questions. The questionnaire was developed by the researchers
Table 1. Distribution of the participants by dental trauma history

\begin{tabular}{llll}
\hline Dental trauma history & $\mathbf{n}$ & $\%$ \\
\hline No & & 695 & 79.4 \\
Yes $^{\text {a }}$ & & 180 & 20.6 \\
& Tooth & 111 & 61.7 \\
& Tooth+tongue/labium/labial mucosa/ & 25 & 13.1 \\
& buccal mucosa/gingiva & & \\
$\quad$ Soft tissue & 34 & 19.6 \\
& (lip/tongue/buccal mucosa/gingiva) & & \\
$\quad$ Maxilla/mandibula & 10 & 5.6 \\
\hline
\end{tabular}

${ }^{a}$ Percentages were calculated in the dental trauma history group $(n=180)$

and had four parts with 31 questions. The first part consists of 10 questions about sociodemographic characteristics of the students. The second part consists of eight questions about dental trauma history, professional sports background, and mouthguard related knowledge and use. The third part consists of one question inquiring if the student can distinguish between the primary and permanent teeth and 10 questions related to dental trauma knowledge of the students. In the fourth part, there are two self-evaluation questions about the opinion on the adequacy of his/her oral dental injury knowledge and educational needs on the topic. Dental trauma knowledge questions were multiple-choice questions in which each question had a single correct answer. In order to facilitate the analysis and presentation of the knowledge questions, the number of true answers was counted for each participant with a minimum value of 0 and maximum of 10 . Then, the authors determined three categories based on the quartiles and median as 0-1: 'low' ( $1^{\text {st }}$ quartile=1), 2-4: 'fair' $\left(2^{\text {nd }}\right.$ quartile=3), and 5-10: 'good' ( $3^{\text {rd }}$ quartile=4).

\section{Statistical analysis}

Data analysis was performed using the Statistical Package for the Social Sciences 20.0 software program (SPSS Inc., Chicago, IL, USA). Frequencies, percent distributions, mean, median, and standard deviation were used for descriptive statistics. The association between categorical variables was tested with the Chi square and Fisher's exact test. The t-test and MannWhitney $U$ test were used for the comparison of means and medians, respectively. The level of significance was determined as $p<0.05$.

\section{Results}

\section{General characteristics}

Approximately $60 \%$ of the participants $(n=875)$ were male, the mean age was $22.5 \pm 2.9$ (min-max: 18-36), and $13.5 \%$ of mothers and $26.3 \%$ of fathers had university or higher education. Among $5.0 \%(n=44)$ of the family members of the students, there was at least one 
Table 2. Participants' knowledge and practice related to mouthguards

\begin{tabular}{|c|c|c|}
\hline Knowledge and practice of mouthguards & n & $\%$ \\
\hline \multicolumn{3}{|l|}{ Aware of mouthguards $(n=875)$} \\
\hline No & 267 & 30.5 \\
\hline Yes & 608 & 69.5 \\
\hline \multicolumn{3}{|l|}{ Wearing mouthguard during sports $(n=608)$} \\
\hline No & 488 & 80.3 \\
\hline Yes & 120 & 19.7 \\
\hline \multicolumn{3}{|l|}{ Mouthguard type $(n=120)$} \\
\hline Custom- fabricated & 40 & 33.3 \\
\hline Stocked & 59 & 49.2 \\
\hline Both & 21 & 17.5 \\
\hline \multicolumn{3}{|c|}{ Necessity of using mouthguards during sporting activities $(n=608)^{a}$} \\
\hline Boxing, kick boxing, taekwondo, judo & 568 & 93.4 \\
\hline American football & 496 & 81.6 \\
\hline Rugby & 391 & 64.3 \\
\hline Ice hockey & 333 & 54.8 \\
\hline Basketball & 316 & 52.0 \\
\hline Wrestling & 288 & 47.4 \\
\hline Handball & 240 & 39.5 \\
\hline Football (soccer) & 175 & 28.8 \\
\hline Skiing & 135 & 22.2 \\
\hline Cycling & 84 & 13.8 \\
\hline Parachuting & 83 & 13.7 \\
\hline Volleyball & 53 & 8.7 \\
\hline Squash & 37 & 6.1 \\
\hline Gymnastics & 35 & 5.8 \\
\hline Diving & 14 & 2.3 \\
\hline Ping pong & 12 & 2.0 \\
\hline Swimming & 11 & 1.8 \\
\hline
\end{tabular}

dentist. Among the students, 44.6\% ( $n=390)$ were interested professionally in at least one sporting activity. Football was played the most $(n=77,19.7 \%)$, followed by volleyball and far-eastern sports ( $n=36,9.2 \%$ each), and athletics $(n=35,8.9 \%)$.

\section{Dental trauma and first aid-emergency training history}

One-fifth of the students $(n=180,20.6 \%)$ had dental trauma history, and of them, $74.8 \%(n=136)$ had tooth or other oral tissue trauma (Table 1). Fifty students $(5.7 \%)$ stated that their first-degree relative had dental trauma history.

Of the participants, $72.0 \%$ stated they had received first aid and emergency training. However, only $21.3 \%$ $(n=134)$ reported that oral dental trauma was mentioned during the training and $20.9 \%(n=183)$ stated they had received some information on oral dental injuries from lectures at university, conferences, or symposiums.

\section{Mouthguard knowledge and practice}

Many had heard about mouthguards (69.5\%) but of these students, only one-fifth $(19.7 \%, n=120)$ stated they used mouthguards when engaging in sports (Table 2). Among them, far-eastern sports professionals had the most mouthguard users with $21.7 \%(n=26)$. The reasons for not using mouthguards were 'not knowing the necessity' (33.0\%), 'thinking unnecessary' (23.3\%), 'not finding comfortable' (16.8\%), 'not knowing how to use' (12.1\%), 'not knowing where to obtain' (11.3\%), and 'not finding it aesthetic' (5.5\%). According to the study results, $25.1 \%$ of the females and $34.1 \%$ of the males had been unaware of mouthguards $(p=0.005)$. Hearing about mouthguards did not significantly differ with the training history about dental injuries $(p=0.76)$. Individual sporting activities as well as awareness and 
Table 3. The proportion of correct answers on the questions related to dental trauma knowledge

\begin{tabular}{ll}
\hline Correct answers $(\mathbf{n}=\mathbf{1 4 5})$ & $\%$ \\
\hline The anterior teeth of children aged 7 years or more are permanent teeth & 59.7 \\
\hline When a permanent tooth is traumatized, emergency intervention is a necessity & 56.8 \\
\hline Replantation is impossible when the primary tooth avulsed & 52.5 \\
\hline The anterior teeth of children aged 6 years or less are primary teeth & 48.3 \\
\hline When a primary tooth is traumatized, emergency intervention is a necessity & 22.5 \\
\hline Replantation is possible when the permanent tooth avulsed & 15.7 \\
\hline Correct practice in case of dental fracture & 9.8 \\
\hline The correct part of the avulsed tooth to hold & $7.1\left(45.3^{a}\right)$ \\
\hline Storage media for the transportation of an avulsed tooth & $2.2\left(13.9^{a}\right)$ \\
\hline Immediate replantation possibility of the avulsed permanent tooth by the teacher & $1.8\left(11.7^{a}\right)$ \\
\hline
\end{tabular}

aAmong the students who answered 'permanent tooth replantation is possible'

use of mouthguards were also evaluated. Football, volleyball, basketball, swimming, gymnastics, and fareastern sports players were aware of mouthguards but mostly far-eastern sports and ice hockey players stated that they used one while engaging in sports.

\section{Dental trauma related knowledge}

Among the students, $33.8 \%(n=296)$ stated that they can distinguish between the primary and permanent teeth. The dental trauma knowledge of the students were assessed with 10 questions and no student answered all questions correctly; only three students $(0.3 \%)$ had 9 correct answers, and $7.8 \%$ had no correct answers (the mean number of correct answers was $2.75 \pm 1.68$ for the whole group, $2.57 \pm 1.68$ for males, and $3.07 \pm 1.61$ for females). The most known three items were 'the distinction of anterior permanent teeth' (59.7\%), 'necessity of emergency intervention for traumatized permanent teeth' $(56.8 \%)$, and 'replantation impossibility of the avulsed primary teeth' (52.5\%), and the least was 'true practice in case of dental fracture' (9.8\%) (Table 3). For the transportation media of avulsed teeth, a glass of ice $(23.4 \%)$, dry paper tissue $(21.2 \%)$, a glass of tap water $(4.4 \%)$, and a glass of hot water $(2.2 \%)$ were chosen. Two-thirds of the students $(60.8 \%)$ were grouped as moderate (2-4 true answers) and $27.1 \%$ as low ( $<2$ true answers). Most of the students (92.3\%) thought they did not have sufficient knowledge. However, only $66.6 \%$ stated that they wish to learn more about the topic.

The number of true answers significantly differed by sex (females $>$ males, $p=0.002$ ) and having any training about dental injuries (trained $>$ not trained, $p=0.004$ ). Among the students who evaluated themselves as having enough dental trauma knowledge, $41.8 \%$ were in the 'low level', and the difference was statistically significant $(p \leq 0.001$; Table 4$)$.

\section{Discussion}

In sporting activities, athletes might be exposed injuries, which results in aesthetic, functional, physiological, and economic problems. From this view point, the importance of prevention increases. ${ }^{2}$ Sports-related dental and orofacial injuries are preventable, or at least reducible, by using the proper equipment when performing risky sporting activities. ${ }^{8}$

There are various studies about the use of mouthguards by professional athletes of different branches ${ }^{11,16}$ and coaches. ${ }^{3}$ The results of some studies performed on coaches-athletes, ${ }^{3}$ physical education teachers/sport education teachers/dentists, ${ }^{17,18}$ high school students, ${ }^{19}$ sports participants, ${ }^{20}$ basketball, ${ }^{21}$ soccer, ${ }^{22}$ and ice hockey players ${ }^{23}$ show the low level of mouthguard use and knowledge related to tooth avulsion and dental emergencies. Furthermore, to our knowledge, there are few studies conducted on this issue in Turkey ${ }^{3,19-23}$ and there is no study about both dental trauma knowledge and mouthguard use of students in Sport Sciences Faculties. In the current study, the results illustrating the low level of dental trauma knowledge (67.7\%) and mouthguard use $(19.7 \%)$ were similar to the literature.

One in five participants $(20.6 \%)$ had dental trauma history, and of these students, $74.8 \%$ had tooth or tooth and tissue injuries. Although it was not evaluated if the student had a trauma history while doing a professional sporting activity, the evaluation of interest in professional sporting activity and dental trauma history showed more than $20.0 \%$ of basketball, athletics, horse-riding, ice skating, and far-eastern sports players had dental trauma history while $15.0 \%-20.0 \%$ of tennis, volleyball, and swimming athletes had. All 3 ice hockey players and 20 of taekwondo professional players had trauma history. According to the results of other studies, levels of dental trauma history range from $10.9 \%$ to $33.1 \% .^{17,23-25}$ Lieger et al. ${ }^{11}$ reports that of the participants interested in sports with high trauma risk and a trauma history, $41.0 \%$ had a tooth injury, which is similar to this study's results.

Properly-fitted mouthguards are mandated in all collision and contact sports such as ice hockey, football, lacrosse, and skateboarding. ${ }^{2}$ Most of the participants 
Table 4. Distribution of dental trauma knowledge levels by some student characteristics

\begin{tabular}{|c|c|c|c|c|c|}
\hline \multirow[b]{2}{*}{ Characteristics } & \multicolumn{5}{|c|}{ Dental trauma knowledge level $\left(n, \%^{a}\right)$} \\
\hline & Low & Moderate & High & Total & p \\
\hline Sex & & & & & $\leq 0.001^{b}$ \\
\hline Female & $64(18.4)$ & $226(65.1)$ & $57(16.4)$ & 347 & \\
\hline Male & $173(32.8)$ & $306(58.0)$ & $49(9.3)$ & 528 & \\
\hline Dentist among family members & & & & & $0.988^{c}$ \\
\hline No & $225(27.1)$ & $505(60.8)$ & $101(12.2)$ & 831 & \\
\hline Yes & $12(27.3)$ & $27(61.4)$ & $5(11.4)$ & 44 & \\
\hline Dental trauma history of the student & & & & & $0.257^{b}$ \\
\hline No & $197(28.3)$ & $415(59.7)$ & $83(11.9)$ & 695 & \\
\hline Yes & $40(22.2)$ & $117(65.0)$ & $23(12.8)$ & 180 & \\
\hline Dental trauma history in the family & & & & & $0.285^{\circ}$ \\
\hline No & $227(27.5)$ & $501(60.7)$ & $97(11.8)$ & 825 & \\
\hline Yes & $10(20.0)$ & $31(62.0)$ & $9(18.0)$ & 50 & \\
\hline First aid and emergency training & & & & & $0.076^{b}$ \\
\hline No & $78(31.8)$ & $144(58.8)$ & $23(9.4)$ & 245 & \\
\hline Yes & $159(25.2)$ & $388(61.6)$ & $83(13.2)$ & 630 & \\
\hline Oral dental health training & & & & & $0.259^{b}$ \\
\hline No & $196(28.3)$ & $415(60.0)$ & $81(11.7)$ & 692 & \\
\hline Yes & $41(22.4)$ & $117(63.9)$ & $25(13.7)$ & 183 & \\
\hline Self-reported oral dental health knowledge & & & & & $\leq 0.001^{b}$ \\
\hline Not Enough & $122(20.4)$ & $396(66.3)$ & $79(13.2)$ & 597 & \\
\hline Enough & $8(11.9)$ & $40(59.7)$ & $19(28.4)$ & 67 & \\
\hline Have no idea & $107(50.7)$ & $96(45.5)$ & $8(3.8)$ & 211 & \\
\hline Total & $592(67.7)$ & 277 (31.7) & $6(0.6)$ & 875 & \\
\hline
\end{tabular}

${ }^{a}$ Row percentages, ${ }^{b}$ Fisher exact test, ${ }^{c}$ Chi square test

mentioned the necessity of using mouthguards while performing sporting activities and $69.5 \%$ heard about the protective function of mouthguards, similar to the results of various studies in the literature: $96.0 \%$ of taekwondo athletes, ${ }^{16} 77.6 \%$ of physical education teachers, $36.5 \%$ of high school students, ${ }^{17} 72.2 \%$ of coaches, ${ }^{3} 62.0 \%$ of ice hockey players, ${ }^{23} 56.0 \%$ of athletes, ${ }^{11}$ and $55.4 \%$ of sport participants ${ }^{20}$ knew the mouthguard's function. In this study, mostly football, volleyball, basketball, swimming, gymnastic, and fareastern sports professional players were aware of mouthguards. However, only far-eastern sports players used them while engaging in sports. This is in parallel with the literature results that knowing the protective function of mouthguards does not mean athletes use them. ${ }^{3,11,20,23}$

The American Society for Testing and Materials classifies mouthguards in three categories: customfabricated, mouth-formed guards, and stock. ${ }^{8}$ Custommade mouthguards are the most predictable and effective. ${ }^{8}$ Of the mouthguard-using participants, $33.3 \%$ used custom-fabricated and $17.5 \%$ used mouth-formed or stock mouthguards. Custom-made mouthguard use was $90.0 \%$ in Lieger et al. ${ }^{11}$ and $5.3 \%$ in Viodvic et al. ${ }^{16}$ In this study, the reasons for not using mouthguards were 'not finding aesthetic and/or comfortable', 'not knowing the necessity', 'thinking unnecessary', and 'not knowing how to use'. These answers, except for 'not finding aesthetic and/or comfortable', might be related to the lack of knowledge on the topic. In addition, 'expensiveness' has been stated for not using mouthguards in a study of professional athletes. ${ }^{11}$

When dental trauma occurs, the type of the tooth (permanent/primary) and the injury must be examined carefully. Of all students, $59.7 \%$ gave the correct answer to the question 'whether the traumatized tooth is primary or permanent according to the age of the child', which was a higher proportion than in Chan et al. $(47.0 \%) .^{13}$ In dental trauma occurrence, immediate intervention is needed to avoid or minimize complications. Most students $(56.8 \%)$ knew the urgent need for intervention for a traumatized permanent tooth, similar to Sepet et al. (55.5\%). ${ }^{20}$ However, this rate was less than in other studies evaluating knowledge of the need 
for urgent professional intervention for avulsed teeth $\left(61.4 \%^{13}\right.$ and $\left.64.1 \%{ }^{24}\right)$. One in eight students $(15.7 \%)$ answered correctly about the replantation possibility of avulsed permanent teeth. This finding is less than some other study results: $37.3 \%,{ }^{20} 38.9 \%,{ }^{24}$ and $43.6 \% .{ }^{16}$ Of the students who knew the possibility of replantation, $11.7 \%$ stated that they could perform this process, which is higher than in Chan et al., ${ }^{13}$ but less than in Alencar et al. ${ }^{26}$ with physical education teachers. Al-Arfaj et al. reported that $40.3 \%$ of athletes have re-implanted someone's avulsed tooth. ${ }^{25}$ This higher proportion might be related to of time spent in professional sports.

In the case of avulsion, the duration the tooth stays dry is related to the risk of root resorption after repositioning. It is therefore important that the avulsed tooth be kept in suitable storage conditions (Hank's balanced salt solution, milk, saline, etc.), so that the fibers surrounding the root remain alive and is replaced quickly without touching the root surface. ${ }^{27}$ Of all participants, only $2.2 \%$ knew the answer (a glass of cold milk) about the storage media of transporting the avulsed tooth. In the literature, knowing milk as the storage media was reported as $3.6 \%,{ }^{13} 5.3 \%,{ }^{24} 9.1 \%,{ }^{20}$ and $11.4 \% .{ }^{19}$

In case of a dental fracture, the fractured part needs to be placed in a glass of milk and taken to the dentist as soon as possible for bonding. This study's results showed that $9.8 \%$ of the students knew this correct practice. However, Saritekin et al. ${ }^{17}$ reported that only $3.5 \%$ of physical education teachers knew this.

According to the findings of this study, $72.0 \%$ of the students had first aid and emergency intervention training, similar to Natarajan et al. $(71.0 \%)^{24}$ and Chan et al. ${ }^{13}(75.0 \%)$ but higher than Alencar et al. ${ }^{26}$ (46.5\%). Among the participants who had first aid and emergency training, $21.3 \%$ stated that information was given about oral and dental trauma, which was almost four times more than in Alencar et al. (4.4\%). ${ }^{26}$ Apart from first aid training, $20.9 \%$ of the students had training regarding oral dental injuries. In the literature, this proportion was between $5.4 \%$ and $33.5 \% .^{13}$ These findings suggest that the content of first aid and emergency intervention trainings needs to be more comprehensive related to dental trauma.

Among the students, $7.7 \%$ thought that they had adequate dental trauma knowledge and two-thirds stated that they wished to learn more about the topic. In a study held with teachers, $25.9 \%$ were satisfied about their knowledge related to dental trauma, ${ }^{26}$ which is higher than the current study. Similar to this study, some studies about the dental trauma knowledge of physical education teachers ${ }^{13,14}$ and teacher candidates ${ }^{26}$ show education is needed on the topic. The results show that the students do not have enough knowledge about dental trauma emergency procedures similar to studies comprising participants in sport activities. 3,19,20,23-25

There were some limitations in this study. First, school attendance was not compulsory at the survey sites, and this might decrease the coverage rate. In ad- dition, the time spent in professional sports and the age at trauma was not asked. Memory bias could have occurred, also.

\section{Conclusion}

In conclusion, Sport Sciences Faculty students had an inadequate level of knowledge about dental trauma in general and protection from dental trauma by means of mouthguards.

\section{REFERENCES}

1. Tuna EB, Ozel E. Factors affecting sports-related orofacial injuries and the importance of mouthguards. Sports Med 2014;44:777-83.

2. American Association of Pediatric Dentistry (AAPD). Policy on Prevention of Sports-related Orofacial Injuries. In: Oral Health Policies \& Recommendations(The Reference Manual of Pediatric Dentistry). 2019-2020/P.97-102.https://www.aapd.org/research/oral-healthpolicies--recommendations/prevention-of-sports-related-orofacialinjuries/. Access date: 23.12.2019.

3. Cetinbas T, Sonmez H. Mouthguard utilization rates during sport activities in Ankara, Turkey. Dent Traumatol 2006;22:127-32.

4. Hwang K, You SH, Lee HS. Outcome analysis of sports-related multiple facial fractures. J Craniofac Surg 2009;20:825-9.

5. Carniol ET, Shaigany K, Svider PF, Folbe AJ, Zuliani GF, Baredes S, et al. "Beaned": A 5-Year Analysis of Baseball-Related Injuries of the Face. Otolaryngol Head Neck Surg 2015;153:957-61.

6. Piccininni P, Clough A, Padilla R, Piccininni G. Dental and Orofacial Injuries. Clin Sports Med 2017;36:369-405.

7. Cornwell H. Dental trauma due to sport in the pediatric patient. J Calif Dent Assoc 2005;33:457-61.

8. Knapik JJ, Marshall SW, Lee RB, Darakjy SS, Jones SB, Mitchener TA, et al. Mouthguards in sport activities: history, physical properties and injury prevention effectiveness. Sports Med 2007;37:117-44.

9. Marcenes W, al Beiruti N, Tayfour D, Issa S. Epidemiology of traumatic injuries to the permanent incisors of 9-12-year-old schoolchildren in Damascus, Syria. Endod Dent Traumatol 1999;15:117-23.

10. Berger TD, Kenny DJ, Casas MJ, Barrett EJ, Lawrence HP. Effects of severe dentoalveolar trauma on the quality-of-life of children and parents. Dent Traumatol 2009;25:462-9.

11. Lieger $O$, von Arx T. Orofacial/cerebral injuries and the use of mouthguards by professional athletes in Switzerland. Dent Traumatol 2006;22:1-6.

12. Kumamoto DP, Maeda Y. A literature review of sports-related orofacial trauma. Gen Dent 2004;52:270-80; quiz 81.

13. Chan AW, Wong TK, Cheung GS. Lay knowledge of physical education teachers about the emergency management of dental trauma in Hong Kong. Dent Traumatol 2001;17:77-85.

14. Natarajan DK, Gurunathan DD. Knowledge of tooth avulsion and its emergency management among physical education teachers in Chennai. IOSR Journal of Dental and Medical Sciences 2013;11:21-4.

15. Skeie MS, Audestad E, Bardsen A. Traumatic dental injuries-knowledge and awareness among present and prospective teachers in selected urban and rural areas of Norway. Dent Traumatol 2010;26:243-7.

16. Vidovic D, Bursac D, Skrinjaric T, Glavina D, Gorseta K. Prevalence and prevention of dental injuries in young taekwondo athletes in Croatia. Eur J Paediatr Dent 2015;16:107-10.

17. Sarıtekin A, Kırzıoglu Z, Ciftci ZZ. Sports High School Students', Physical Education Teachers' and dentists' Opinion About Mouthguards. J Dent fac Atatürk Uni 2018;28:55-63.

18. Buldur B, Kapdan A. Factors Associated with Knowledge and Attitude of Management of Traumatic Dental Injuries: A Cross-Sectional Study among Turkish Dentists. Pesq Bras Odontoped Clin Integr 


\section{8;18:e3948.}

19. Kapdan A, Buldur B, Kapdan A, Unal M, Kustarcı A. Spor Eğitimi Gören öğrencilerin, dişlerin avulsiyon ve replantasyonu hakkındaki ilk yardım bilgi düzeyinin belirlenmesi. Cumhuriyet Dent J 2011;14:191203.

20. Sepet E, Aren G, Dogan Onur O, Pinar Erdem A, Kuru S, Tolgay CG, et al. Knowledge of sports participants about dental emergency procedures and the use of mouthguards. Dent Traumatol 2014;30:391-5.

21. Tiryaki M, Saygi G, Yildiz SO, Yildirim Z, Erdemir U, Yucel T. Prevalence of dental injuries and awareness regarding mouthguards among basketball players and coaches. J Sports Med Phys Fitness 2017;57:1541-7.

22. Dursun E, Ilarslan Y, Ozgul Ozkan Y, Donmez G. Prevalence of dental trauma and mouthguard awareness among weekend warrior soccer players. J Oral Sci 2015;57:191-4.

23. Caglar E, Kargul B, Tanboga I. Dental trauma and mouthguard usage among ice hockey players in Turkey premier league. Dent Traumatol 2005;21:29-31.

24. Natarajan K, Gurunathan D. Knowledge of tooth avulsion and its emergency management among physical education teachers in Chennai. IOSR Journal of Dental and Medical Sciences 2013;11:21-4.

25. Al-Arfaj I, Al-Shammari A, Al-Subai T, Al-Absi G, AlJaffari M, AlKadi $A$, et al. The knowledge, attitude and practices of male sports participants to sports-related dental trauma in Khobar and Dammam, Saudi Arabia - A pilot survey. Saudi Dent J 2016;28:136-41.

26. Alencar AHG, Bruno KF, Freire MCM, Moraes MR, Queiroz LB. Knowledge and attitudes of physical education undergraduates regarding dental trauma Dental Press Endod 2012;2:74-9.

27. Andersson L, Andreasen JO, Day P, Heithersay G, Trope M, Diangelis AJ, et al. International Association of Dental Traumatology guidelines for the management of traumatic dental injuries: 2. Avulsion of permanent teeth. Dent Traumatol 2012;28:88-96.

\section{Türk spor bilimleri fakültesi öğrencileri dental travma ve ağız koruyucular hakkında ne biliyor? Tanımlayıcı bir araştırma}

\section{Özet}

AmAÇ: Sporla ilgili diş ve orofasiyal yaralanmalar, birincil korunma eğitimleri ve spor aktivitesi sırasında uygun ekipmanın kullanılmasıyla önemli ölçüde azaltılabilir. Bu çalışmanın amacı, Spor Bilimleri Fakültesi öğrencilerinin diş travması ve ağız koruyucuları ile korunma konusundaki bilgi düzeylerini belirlemektir.

Gereç ve Yöntem: Bu çalışma Ankara, Gazi ve Hacettepe Üniversitelerinde yürütülmüş tanımlayıcı bir araştırmadır. Fakültelerin tüm öğrencilerinin $(\mathrm{N}=3097)$ dahil edilmesi planlanan çalışmaya, veri toplanan gün okulda olan gönüllüler (tüm öğrencilerinin \%28.2) katılmıştır. Veriler öğrencilerin sosyodemografik özelliklerine, dental travma hikayelerine, ağız koruyucu kullanım durumlarına ve dental travma bilgilerine ilişsin toplam 31 sorudan oluşan bir anket aracılığı ile toplanmıştır.

BuLGULAR: Yaş ortalaması $22.5 \pm 2.9$ olan (\%60.3 erkek) 875 öğrenci katılımıştır. Tüm öğrencilerin \%20.6'sında dental travma öyküsü ve \%72.0'ının ilk yardım ve acil durum eğitimi, \%20.9'unun oral-dental yaralanma eğitimi almış olduğu öğrenilmiştir. Öğrencilerin \%69.5'i ağız koruyucusunu duymuşken, \%19.7'si kullandığını belirtmiştir. Ağız koruyucusu kullanımı en sık profesyonel olarak uzak doğu sporları yapan ve buz hokeyi oynayan sporcularda görülmüştür. Öğrencilerin genel dental travma doğru bilgi puanı $2.75 \pm 1.68$ olarak bulunmuştur ve $\% 66.6$ öğrenci bu konu hakkında daha fazla bilgi edinmek istediklerini belirtmiştir.

Sonuç: Bulgular, öğrencilerin hem dental travma hem de ağız koruyucuları hakkında yetersiz bilgilerinin olduğunu ve ağız koruyucularının spor etkinliklerinde yetersiz kullanıldığını göstermiştir. Her iki konuda da temel bilgilerin, öğrencilerin mezuniyet öncesi bilgi edinebilmeleri için müfredatlarına eklenmesi gerektiği düşünülmektedir.

Anahtar Kelimeler: Ağız koruyucu; bilgi; diş avülsiyonu; öğrenciler; spor yaralanmaları; travma 